\title{
Morphological Classification of Nonferrous Wear Particles in Engine Oil Using Pherro- graphical Method
}

\author{
Vladimír Hönig \\ Faculty of Agrobiology, Food and Natural Resources, Department of Chemistry, Czech University of Life Sciences Pra- \\ gue, Kamýcká 129, 165 21, Prague 6 - Suchdol, Czech Republic, E-mail: honig@af.czu.cz
}

Pherrography uses microscopic methods for the detection of morphological characteristics of wear particles deposited on pherrogram. The result of pherrographical analysis is to create the pherrographic track on pherrogram and then to assign the type and intensity of wear. The position of nonferrous metals on the pherrogram is quite clearly defined. Assessment of particle size, particle shape and distinguishing kinds of material are the result of observation. Nonferrous particles are also divided according to the color. Metal particles can, under certain circumstances, have different colors as a result of excessive oxidation of the particle surface. The article deals with the identification of nonferrous particles on pherrographical track of motor oil. This assessment is carried out in relation to the mode of wear of oil and machine. Part of the experiments is also microchemical analysis for subsequent analysis of certain hard identifiable metals.

Keywords: Pherrography, Engine Oil, Wear Particles, Tribotechnical Diagnosis, Pherrographic Track

\section{References}

[1] ALEŠ, Z. (2010). Field experience with transmission oil EP Gear Synth 150, Research in Agricultural Engineering, Vol. 55, pp.18-23. Czech Academy of Agricultural Sciences. Prague. Czech Republic.

[2] ALEŠ, Z., PEXA, M., PAVLU゚, J. (2012). Tribotechnical diagnostics of agricultural machines, Engineering for Rural Development conference Jelgava, 24.-25.05.2012, [online]. [cit.2014-05.01] Available at www: http://www. http://tf.llu.lv.

[3] CELEBRANT, F., ZIEGLER, J., MARASOVÁ, D. (1996). Technická diagnostika a spolehlivost I. Tribodiagnostika. 1. vydání. pp. 110 - 138. VŠB-TU, Ostrava. Czech Republic.

[4] HÖNIG, V., HROMÁDKO, J. (2014). Possibilities of using vegetable oil to power diesel engines as well as their impact on engine oil, Agronomy Research Vol. 12, No. 8, pp. 323 - 332. Estonian Agricultural University. Estonia.

[5] HÖNIG, V., MIHOLOVÁ, D., ORSÁK, M. (2014) Measurement of Wear Metals in Engine Oils by Atomic Absorption Spektrometry Method. Manufacturing Technology, Vol. 14, No. 3, PP. 317 - 322, J. E. Purkyne University in Ústí nad Labem nad Labem. Czech Republic.

[6] HÖNIG, V., SMRČKA, L., HORNÍČKOVÁ, Š. (2014) Application of discriminant analysis in monitoring the wear particles in the engine oil. Manufacturing Technology, Vol. 14, No. 3, pp. 322 - 326, J. E. Purkyne University in Ústí nad Labem nad Labem. Czech Republic.

[7] KEJZLAR, P. (2012). Structure and mechanical properties of Fe-25Al-5Zr and Fe-30Al-5Zr intermetallic alloys. Manufacturing Technology, Vol. 12, No. 13, pp. 131 - 135, J. E. Purkyne University in Ústí nad Labem nad Labem. Czech Republic.

[8] MIHALČOVÁ, J., HEKMAT, H. (2008). Tribotechnická diagnostika v prevádzke použitých olejov I. metódy hodnotenia častíc opotrebovania v olejoch, Chemické listy Vol. 102, pp. 358 - 362. Czech Society of Chemical Engineering, Prague, Czech Republic.

[9] Ministry of Defence CZ. (2007). Instruction for Tribodiagnostics of Engines, Gear and Hydraulic Systems, No. 79: 27/2007:3042, Logistics Division. Prague, Czech Republic

[10]STřIHAVKOVÁ, E., WEISS, V. (2012) The Identification of the structures new type Al-Si-Mg Ca alloys with different Ca content using of the color metallography. Manufacturing Technology, Vol. 12, No. 13, pp. 248 - 251, J. E. Purkyne University in Ústí nad Labem nad Labem. Czech Republic.

[11]STODOLA, J., MACHALÍKOVÁ, J. Spolehlivost a diagnostika BSV. Část: Provozní hmoty a materiály pro MVT. Skriptum. Brno: Vydavatelská skupina UO, Brno. Univerzita obrany, p. 132, ISBN 80-7231-167-0, (2006).

[12] VESELÁ, K.., PEXA, M., MAŘÍK, J. (2014) The effect of biofuels on the quality and purity of engine oil. Agronomy Research, Vol. 12, No. 2, pp. 425 - 430, Estonian Agricultural University. Estonia. 